\title{
Yolsuzluk Algısının Gayrisafi Yurt İçi Hasıla Üzerine Etkisinde Lojistik Performans ile Küresel Rekabetin Ara Değişken Rolü: Türkiye Değerlendirmesi
}

\author{
DOI: $10.26466 /$ opus.522497 \\ * \\ Nagehan Uca* - Mustafa Emre Civelek $^{* *}$ - Murat Çemberci ${ }^{* * * *}$ \\ * Dr. Öğr. Üyesi, İstanbul Ticaret Üniversitesi,İşletme Fakültesi, Sütlüce / İstanbul / Türkiye \\ E-Posta: nuca@ticaret.edu.tr \\ ORCID: $0000-0001-7438-8640$ \\ ** Dr. Öğr, Üyesi., İstanbul Ticaret Üniversitesi, İşletme Fakültesi, Sütlüce / İstanbul / Türkiye \\ E-Posta: ecivelek@ticaret.edu.tr ORCID: 0000-0002-2847-5126 \\ *** Doç. Dr., Yldız Teknik Üniversitesi, İktisadi ve İdari Bilimler Fak., Esenler / İstanbul / Türkiye \\ E-Posta: cemberci@yildiz.edu.tr \\ ORCID: $\underline{0000-0001-8569-4950}$
}

\section{Öz}

Bu araştırmanın amacı yolsuzluk algısının gayrisafi yurt içi hasıla üzerine etkisinde lojistik performans ile küresel rekabetin ara değişken rolünün ortaya konulmasıdır. Bu GSYÏH üzerinde Lojistik performansın dışında başka faktörlerin de etkili olduğunu gösteren çalışmalar literatürde bulunmaktadır. Bu çalışmaların bazılarında yolsuzluk algısının hem lojistik performans hem de GSYIH üzerinde etkili olduğu sonuçları paylaşılmıştır. Çalışmada lojistik performansı yolsuzluk algısı ve küresel rekabet endeksi ile birlikte değerlendiren bir model önerilmiştir. Gerçekleştirilen analiz sonuçlarına göre yolsuzluk algısı ile GSYİH arasındaki ilişkide lojistik performans ve küresel rekabetin ayn anda ara değişken etkisine sahip olduğu istatistiksel olarak anlaml bulunmuştur. Sonuç bölümünde araştırmanın sonuçlarına göre Türkiye değerlendirmesi yapılmıştır. Bu çalışma olarak YAE ve GSYİH ilişkisinde LPE ve KRE endekslerinin rolünü ortaya koyması açısından önemlidir. Bu araştırma lojistik alanında yapılan yatırımların ülke ekonomisine faydasının arttırılması için yapılabilecekler konusunda ışık tutmaktadır. Bu araştırmanın sonuçlarına göre bir ülkenin lojistik performansını artırıcı yatırımlar yapılırken eş zamanlı olarak yolsuzlukla mücadele edilmesi ve küresel rekabette iyileştirici önlemler alınması gerekmektedir.

Anahtar Kelimeler: Lojistik Performans Endeksi, Gayrisafi Yurt İçi Hasıla, Yolsuzluk Algısı Endeksi, Küresel Rekabet Endeksi 


\title{
Mediator Role of Logistics Performance and Global Competition in Relationship between Corruption Perception and Gross Domestic Product: Evaluation of Turkey
}

\begin{abstract}
The aim of this research is to clarify the mediator role of logistic performance and global competition in relationship between corruption perception and gross domestic product. In the literature there are some studies showing that there are other factors besides logistic performance that have effects on GDP. In some of these studies, corruption perception has been found to be influential on both logistic performance and GDP. In this study, a model that evaluates logistics performance together with corruption perception and global competition index is proposed. According to the analysis results, it has been found statistically significant that logistics performance and global competition play mediator role at the same time in the relation between corruption perception and GDP. According to these results, Turkey evaluation has been made. This study is important in terms of the role of LPI and GCI indices in the relationship between CPI and GDP. This research sheds light on what can be done to increase the benefits of investments in the logistics sector to the national economy. According to the results of this research, it is necessary to struggle with corruption and to take remedial measures in global competition while making investments to increase the logistics performance of a country.
\end{abstract}

Keywords: Logistics Performance Index, Gross Domestic Product, Corruption Perception Index, Global Competitiveness Index 


\section{Giriş}

Ülkeler için önemi her geçen gün giderek artan uluslararası ticaret, küreselleşme ve artan rekabetten etkilenmektedir. Bu eğilim; ürünlerin hareketliliğini kolaylaştırması, güvenliği ve hızı arttırması ve uluslararası ticaretin artmasıyla maliyetlerin düşürülmesini sağlayan kilit unsurlardan biri olması yönüyle lojistiği de etkilemektedir (Marti vd., 2017).

Uluslararası ticaretin belkemiğini oluşturan lojistik; yük taşımacılığı, depolama, ödeme sistemleri ve özellikle mal sahipleri için özel hizmet sağlayıcılar tarafından gerçekleştirilen diğer birçok fonksiyonu kapsamaktadır. Bununla birlikte, lojistik ulusal hükümetlerin, bölgesel ve uluslararası kuruluşların kamu politikalarını belirlemelerinde de önemli rol oynamaktadır (Arvis vd., 2012).

Son yıllarda, ülkeler açısından lojistiğin önemi arttıkça, lojistiğin performansının ölçülmesi de ülkeler için önemli hale gelmiştir. Lojistik performans, ülkelerin büyümeleri üzerinde etkili olan ve yabancı yatırımların tercihini etkileyebilen önemli bir faktör olarak görülmektedir (Çelebi vd., Civelek, 2015). Çünkü bir ülkenin küresel düzeyde ticaret yapma kabiliyeti, büyük ölçüde diş ticaret aktörlerinin lojistik ağlarına erişimlerinin etkinliğine bağlıdır (Ekici vd., 2016).

Lojistik performans ülkelerin gelir düzeyleri ve coğrafi konumları ile de ilişkilidir. Nitekim Marti ve diğerleri (2017)'nın yapmış oldukları araştırmada lojistik performansın büyük oranda ülkelerin gelirlerine ve bulundukları coğrafik bölgelere bağlı olduğunu ortaya koymuşlardır. Örneğin, Avrupa Birliği ülkelerinin yüksek gelir grubunda olanlarının lojistik performanslarının yüksek olduğu görülür.

Lojistik performans ile ilgili diğer bir husus da lojistik performansın ülkelere sağlayacağı kazanımları en üst seviyeye çıarmak için ne yapılması gerektiği hususudur. Ülkelerin yüksek lojistik performanslarının avantajlarından yararlanabilmeleri için küreselleşmenin gerektirdiği düzenlemelere hazır olmaları gerekmektedir. Başka bir ifade ile ülkeler lojistik performansı belirleyen ortak standartları dikkate alıp geliştirdikleri oranda lojistik performanslarının avantajlarından yararlanabileceklerdir (Sandberg ve Abrahamsson, 2011). Bu nedenle, dünya 
genelinde lojistik performansı ölçmek için uygun bir nicel araç gerekmektedir. Bu gerekliliği gidermek için Lojistik Performans Endeksi geliştirilmiştir.

Lojistik Performans Endeksi (LPE) tedarik zincirini ölçmek için ülkeler bünyesinde yer alan ihracat şirketlerinden toplanan anketlerde yer alan verilere dayanmaktadır. LPE ilk olarak 2007'de yayınlanmış ve dünyada ekonomik büyümede lojistik performansın önemi üzerine küresel bir tartışma başlamasına sebep olmuştur. Aynı zamanda, LPE gelecekteki performansı iyileştirmek için somut politikaların uygulanması ihtiyacını da ortaya koymaktadır. LPE ve bileşenleri, ülkelere iş ortaklarını daha yakından tanımaları ve rekabetçiliklerine zarar verebilecek muhtemel düzenlemeleri öngörmeleri konusunda da yardımcı olmaktadır (Andersson vd., 1989).

Lojistik performansın doğrudan etkilediği ekonomik büyüme, bir ülkede üretim kapasitesinin, üretimin ve dolayısıyla milli gelirin artmasını ifade eder. Ülkeler için önemli göstergelerden biri olan Gayri Safi Yurt içi Hasıla (GSYİH) rakamları ekonominin genel durumu hakkında bilgi veren sayısal verilerdir. Literatürde lojistik performansın ülke ekonomilerinin büyümesinde önemli etkilere sahip olduğunu gösteren çalışmalar mevcuttur . D'Aleo ve Sergi (2017) çalışmalarında lojistik sistemlerle ekonomik büyüme arasında pozitif yönlü ilişki olduğunu ortaya koymuşlardır (D'Aleo ve Sergi, 2017). Esfahani ve Ramirez (2003) çalışmalarında Lojistik performansın alt boyutlarından alt yapının ekonomik büyüme için önemli rol oynadığını ortaya çıkarmışlardır (Esfahani ve Ramirez, 2003). Hu ve diğerleri lojistik altyapısına yapılan yatırımlar ile GSYH arasında Granger nedensellik testi uygulayarak anlamlı bir ilişki bulmuşladır (Hu vd., 2012). Wang ve Choi (2018) yaptıkları çalışmada gelişmekte olan ülkelerin rekabetçiliklerini geliştirebilmeleri için gümrük işlemleri, izlenebilirlik ve altyapıya öncelik vermeleri gerektiği sonucuna ulaşmışlar.

Çelebi ve diğerleri (2015) çalışmalarında, lojistik performans ile ekonomik büyüme arasında pozitif yönlü ilişki olduğunu belirtmişlerdir. Bu etkiyi doğrudan yabancı yatırımların ülkeyi tercih etme nedenleri ile birleştiren çalışmada, ülkelerin doğrudan yabancı yatırımları çekmesinde yabancı yatırımcıların dikkate aldıkları en önemli kriterin ülkelerin lojistik olanakları olduğu ifade edilmiştir. Aynı araştırmanın bir diğer sonucuna 
göre ise doğrudan yabancı yatırımların ekonomik büyüme üzerine etkisinde lojistik performans göstergelerinin çok etkili olduğu ifade edilmiştir. Küresel pazarlarda yatırım olanakları arayan uluslararası sermaye, bu sermayeyi büyütecek üretim sistemleri kurmanın ötesinde kaynaklara erişim, ürün hareketliliği, bürokratik serbestlik, izlenebilirlik ve şeffaflık gibi kolaylıklar da aramakta olduğu da belirtilmiştir (Çelebi vd., 2015).

Uca ve diğerleri (2015) lojistik performans endeksinin boyutlarından gümrüklerin ve gümrükleme süreçlerinin verimliliği ile ticaret ve taşımacılıkla ilgili altyapı kalitesi ile GSYİH arasında pozitif yönlü ilişki olduğunu ileri sürmüşlerdir. Bu araştırmaya göre, ülkedeki gümrüklerin ve gümrükleme süreçlerinin iyileştirilmesi ile ticaret ve taşımacılıkla ilgili altyapı kalitesini yükseltecek yatırımların yapılmasının ülkenin GSYİH'sında bir artışa sebep olacağı ifade edilmektedir (Uca vd., 2015).

Literatürde lojistik performansın ülkelerin ekonomik büyümelerinde giderek artan öneme sahip olması yanında; rekabetçilik, yenilikçilik, girişimcilik ve yolsuzluk algısı gibi kavramlarla da ilişkili olduğunu açıklayan birçok çalışma vardır (Akkuş, 2014; Akıncı vd., 2015; Alas ve Miller, 2009; Andvig vd., 2001; Erkan, 2014; Fawcett ve Cooper, 1998; Founou, 2002; Hu vd., 2012; Mohan, 2013; Ojala ve Queiroz, 2002; Overbaugh, 2013; Civelek vd., 2015; Puertas vd., 2013).

$\mathrm{Bu}$ araştırmanın kurgusunda KRE bir değişken olarak kullanılmasının nedeni, KRE'nin ekonomik büyüme ve uzun dönemli refahın sürdürülebilir olması için, ülkeler arasında karşılaştırma olanağı sağlayan en kapsamlı değerlendirme araçlarından biri olmasıdır. Ülkelerin küresel düzeyde rekabetlerini açklayan ve ülkeleri rekabetçilik düzeylerine göre sıralayan Küresel Rekabet Endeksi (KRE) de lojistik performans ile ilişkisi olan bir başka değişkendir (Ekici vd., 2016).

KRE uzun ve kısa vadede ülkeleri kurumsal ve ekonomik açıdan değerlendirmektedir. Endeksin hesaplanmasında 12 gösterge kullanılmaktadır. Bu göstergeler; kurumlar, altyapı, makroekonomik çevre, sağlık ve ilköğretim, yükseköğretim, ürün pazar verimliliği, finansal pazarların gelişimi, iş gücü pazarının verimliliği, teknolojik hazırlık, pazar payı, yenilik ve iş karmaşıklı̆̆ıdır (Schwab, 2014). Çemberci ve diğerleri (2015) yapmış oldukları çalışmalarında, küresel rek- 
abette üst sıraları hedefleyen ülkelerin, lojistik performans göstergelerinden uluslararası taşımacılık, takip ve izleme ile zamanlama boyutlarında önemli iyileştirmeler yapması gerektiğini ileri sürmüşlerdir (Çemberci vd., 2015). Civelek ve diğerleri (2015) ise lojistik performans, küresel rekabet ve ekonomik büyüme arasındaki ilişkileri araştırdıkları çalışmalarında, küresel rekabetin ülkelerin büyümeleri üzerinde etkili olduğunu, bununla birlikte bir ülkenin lojistik performansının rekabetçilik ile büyüme arasındaki ilişkiyi domine ettiğini ortaya atmışlardır (Civelek vd., 2015).

Yolsuzluk ve rüşvet gibi olayların bir ülkenin gümrüklerinde ve lojistik ile ilgili diğer bürokratik süreçlerinde görülüyor olması ülke içerisinde ithalat ve ihracat yapan firmaların maliyetlerine yansımaktadır. Bu maliyetlerin ülke ekonomisini olumsuz etkilediği düşünüldügünden araştırma kurgusunda Yolsuzluk Algısı Endeksi öncül bir değişken olarak yer almaktadir.

Literatürde, ülkelerdeki yolsuzluk algisının, küresel rekabet, lojistik performans ve ekonomik büyüme üçgeninde de etkilerinin olduğu gösteren çalışmalar mevcuttur. Ülkelerdeki yolsuzluk algısı bir endeks aracıyla belirlenmekte ve ülkeler yolsuzluk seviyelerine göre sıralanmaktadırlar. Yolsuzluk Algısı Endeksi (YAE), operasyonel raporlardan ve uzmanlardan alınan yolsuzluk verilerini birkaç bağımsız ve güvenilir kurumda derleyerek hazırlanan bileşik bir endekstir. Endeks, değerlendirilen ülkelerde yaşayan kişilerle birlikte uzmanların görüşlerini de yansıtmaktadır. Endekste kullanılan yolsuzluk algısı, ilgili ülkedeki yolsuzluğun gerçek seviyesinin anlaşılması için bilgi vermektedir. Uca ve diğerleri (2016) yolsuzluk algısının lojistik performans ve diş ticaret hacmi ile ilişkisini araştırdıkları çalışmalarında, ülkelerdeki yolsuzluk algısının lojistik performans üzerinden diş ticaret hacmini etkilediğini ortaya koymuşlardır. Bu çalışmaya göre, ülkeler her ne kadar lojistik performanslarını artırmaya yönelik iyileştirmeler, düzenlemeler ve yatırımlar yapsalar bile ülkedeki yolsuzluk algısının yüksek olması dış ticaret hacimlerinin artmasında olumsuz etki yaratmaktadır. Dolayısıyla ülkeler dış ticaret hacimlerinde olumlu bir etki yaratmak için lojistik performanslarını artırmaya yönelik çalışmaların öncesinde ülkedeki yolsuzluk algısının düşük olması gerekir. Yolsuzluk algısının yüksek olduğu ülkelerde lojistik altyapı ve yatırımlar yeterli olsa bile ticaretin ve sosyal yapının 
güvensiz oluşu dış ticarete olumsuz etki eder. Yabancı yatırım açısından bakıldığında, yabancı yatırımcılar kurumsal yapının güvenilir olmadığı ülkelere yatırım yapmak istemezler. Çünkü böyle bir ortamda lojistik performansın iyi olması tek başına bir şey ifade etmemektedir (Uca vd., 2016).

$\mathrm{Bu}$ araştırmada, yolsuzluk algısının gayrisafi yurt içi hasıla üzerine etkisinde lojistik performans ile küresel rekabetin ara değişken rolünün ortaya konulması amaçlanmıştır. Lojistik performansı yolsuzluk algısı ve küresel rekabet endeksi ile birlikte değerlendiren bir model önerilmiştir. Çalışmanın 88 ülke kapsamında bulunan sonuçlarına göre Türkiye açısından çıkarımları yorumlanmıştır.

\section{Kavramsal Temeller}

\subsection{Yolsuzluk Algisi}

Yolsuzluk çok eski zamanlardan beri var olan bir kavram olup tanımlanması zor olsa da, literatürde yolsuzluk hakkında yapılmış bazı tanımlamalar mevcuttur. Kaufmann (1997) yolsuzluğu kamu çalışanlarının, kamu malını kendi çıkarları için kötüye kullanması olarak tanımlamıştır. Kaufmann (1997), ticari faaliyetlerde kişilerin rüşvet vererek idari yapıdaki engelleri aşabildiğine de dikkat çekmiş, yolsuzluk ve bürokrasi arasındaki ilişki üzerinde durmuştur (Kaufmann, 1997). Klitgaard (1998) ise çalışmasında, yolsuzluğun farklı şekillerde olabileceğini, sadece rüşvet alma veya zimmete para geçirme şeklinde değil, dolandırma, rüşvet verme gibi farklı türlerde de olabileceğini belirtmiş ve yolsuzluk ile şeffaflık arasında ilişki olduğunu ifade etmiştir (Klitgaard, 1988).

Tanzi (1998) yolsuzluğu tanımlamanın o kadar da kolay olmadığı konusuna değinerek, kamu gücünün kişisel çıkarlar amacıyla kötü amaçlı kullanılması açıklamasını desteklemiştir. Tanzi (1998)'ye göre yolsuzluk kamu gücünü kendi amaçları için kullanma, rüşvet, adam kayırma, hediye alma, para çalma, kamu malına zarar verme gibi etik ve legal olmayan kavramları içermektedir (Tanzi, 1998).

Literatürde yolsuzlukla ilgili çeşitli sınıflandırmalar yapılmaktadır ancak genel anlamda yolsuzluk ekonomik ve politik yolsuzluk olarak 
sinıflandırılabilmektedir (Güney, 2013). Bunun yanında literatürde yolsuzluk ve yolsuzluk algısı hakkında yapılan çalışmalar mevcuttur. Örneğin; Tanzi ve Davoodi (1998) çalışmalarında, yolsuzluğun toplum üzerinde sosyal, siyasal, sosyolojik ve ahlaki etkileri olduğu gibi, ülkelerin makroekonomik performansları üzerinde de etkisi bulunduğunu açıklamışlardır (Tanzi ve Davoodi, 1998).

Sanyal (2005) araştırmasında, rüşvet ve yolsuzluk algısı arasındaki ilişkiyi ekonomik ve kültürel değişkenler ile çoklu regresyon analizi yöntemini kullanarak incelemiş ve hem ekonomik hem de kültürel faktörlerin rüşvet için önemli açıklayıcı faktörler olduğu sonucuna ulaşmıştır (Sanyal, 2005).

Morse (2006) çalışmasında, çevresel sürdürülebilirlik ile yolsuzluk algısı endeksi arasındaki ilişkiyi lineer regresyon yöntemi ile analiz etmiş ve yolsuzluk ile çevresel sürdürülebilirlik arasında önemli bir ilişki olduğunu ortaya koymuştur (Morse, 2006).

Dökmen (2012) çalışmasında yolsuzlukların vergi gelirleri üzerindeki etkisini dinamik panel tahmin yöntemi ile incelemiş ve yolsuzluklarla farklı vergi türleri arasında negatif ve istatistiksel açıdan anlamlı ilişki olduğunu ileri sürmüştür (Dökmen, 2012).

Özcan (2012) ise çalışmasında, OECD ülkelerinde yolsuzluğun ekonomik belirleyenlerini panel veri analizi yöntemi ile incelemiş, gelir eşitsizliğinin yolsuzluğu arttırdığını, ekonomik özgürlük düzeyinin artmasının ise yolsuzluk düzeyini azalttığını ortaya koymuştur (Özcan, 2012).

Şahbaz ve diğerleri (2013) çalışmalarında kurumsal faktörlerin ve yolsuzluk algısının kamu borcu üzerindeki etkisini yatay kesit analiz yöntemi ile test etmişler ve yolsuzluk algısını azaltmanın kamu borçlarını azalttığı sonucuna ulaşmışlardır (Şahbaz vd., 2013).

Wright ve Craigwell (2013) yaptıkları araştırmada, yolsuzluk algısı ile ekonomik büyüme arasındaki ilişkiyi lineer ve lineer olmayan panel nedensellik testi ile incelemişlerdir. Gelişmekte olan ekonomilerde özellikle ekonomik büyüme dönemlerinde ve sonrasında zararları azaltmak için yeterli kurumsal olanaklar mevcut olmalıdır sonucuna ulaşmışlardır (Wright ve Craigwell, 2013). 
Yakışık ve Çetin (2014), yolsuzlukların sosyo-ekonomik belirleyicilerini inceledikleri "Yatay Kesit Veri Analizi" isimli çalışmalarında 4 farklı modelle yolsuzluğun belirleyicilerini tahmin etmişlerdir. Elde edilen sonuçlara göre özgürlük, demokrasi ve kişi başı gelir değişkenlerdeki artışların yolsuzlukları pozitif (iyileşme) yönde etkilediği, kamu harcama oranı değişkenindeki artışın ise yolsuzlukları negatif (olumsuz) yönde etkilediğini ileri sürmüşlerdir (Yakışık ve Çetin, 2014).

Fernández ve Velasco (2014) İspanya'da kayıt dışı ekonomi, kamu borcu ve yolsuzluk üzerine bir çalışma yapmışlar, kayıt dışı ekonomi hacminin, bölgesel kamu borcuna önemli ve olumlu bir etkisi olduğunu ileri sürmüşlerdir (Fernandez ve Velasco, 2014).

Akkuş (2014) çalışmasında, “Türkiye'de Yolsuzluk Bibliyografyası"nı çıkarmış ve Türkiye'de sosyal bilimler ulusal veri tabanına kayıtlı olan yolsuzlukla doğrudan ya da dolaylı bir biçimde ilgili çalışmaları derlemiştir (Akkuş, 2014).

Akıncı ve diğerleri (2015) çalışmalarında ekonomik özgürlükler ile yolsuzluk arasındaki ilişkiyi zaman serisi yöntemi ile incelenmişler; finansal özgürlükler, mali özgürlükler, mülkiyet hakları, parasal özgürlükler ve ticari özgürlüklerin, yolsuzlukların azalmasına neden olduğunu destekler bulgulara ulaşmışlardır (Akıncı vd., 2015). Türkay (2015) araştırmasında Yolsuzluk Algılama Endeksini incelemiş ve Türkiye'nin yolsuzluk algısındaki durumunu konu almıştır (Türkay, 2015).

Yolsuzluk ile ilgili diğer bir konu da yolsuzluğun ülkeler bazında ölçülmesi ile ilgilidir. Günümüz ölçüm metotlarıyla yolsuzluk seviyesini hatasız olarak belirlemek mümkün olmasa da uluslararası otoriteler ve bilim insanları tarafından kullanılan, anketler ve çeşitli kaynaklardan aldığı veriler ile dolaylı olarak yolsuzluğu ölçen çeşitli ölçüm araçları bulunmaktadir.

Saha araştırmaları ile yolsuzluk hakkında bilgi edinilebilir. Dünya'da birçok organizasyon, yerel ve küresel ölçekte araştırmalar yaparak, sonuçlarını analiz etmekte ve yolsuzlukla mücadele amacıyla bu bilgileri paylaşmaktadır. Bazı kuruluşlar ise bu sonuçları endekslere dönüştürerek, ülkelerdeki organizasyonların yolsuzluk alg1 düzeylerinin ölçülmesini sağlamaktadır (Tanzi, 1998). Yolsuzluk algısı, kişi ve organizasyonların yolsuzluk eylemlerinde yer alıp almamalarının yanı sıra, 
kendilerinin yapmadıkları fakat günlük hayatlarında çeşitli şekillerde algıladıkları veya karşılaştıkları yolsuzlukları da içermektedir. Bu anlamda Yolsuzluk Algı Endeksi (YAE) saha araştırması içeren, farklı kaynaklardan, farklı ülkelerden elde edinilen verilerin uzmanlar tarafından, çeşitli bilimsel yöntemler kullanılarak, analiz edildiği bir endekstir. YAE, uluslararası kuruluşların hazırladığı endeksler içerisinde güvenilir bir kaynak olarak kabul edilmekte ve önemli bir yer tutmaktadır. Endeks, yolsuzluğu değil yolsuzluğun algılanmasını ölçmekte olup, yolsuzluğa bulaşmış yetkililerle karşılaşma olasılığını, kamu kaynaklarının özel çıkarlar için kullanılmasını, rüşvet ve zimmete geçirme kavramları üzerine yoğunlaşmaktadır. Bu endeks çeşitli bağımsız araştırma kuruluşlarından gelen verilerle hazırlanmaktadır. Yolsuzluk algı endeksi özel sektör ile ilgili yolsuzluklarla doğrudan ilgili olmayıp, kamu sektörü çalışanlarının ne düzeyde yolsuzluğa karıştığını belirlemek için kullanılmaktadır.

Bu çalışmada, yolsuzluk algısı Yolsuzluk Algı Endeksi (YAE) ile ölçülmüştür. Endeks, yolsuzluğu değil yolsuzluğun algılanmasını ölçmekte olup, yolsuzluğa bulaşmış yetkililerle karşılaşma olasılığını, kamu kaynaklarının özel çıkarlar için kullanılmasını, rüşvet ve zimmete geçirme kavramları üzerine yoğunlaşmaktadır. Endeks ülkeleri, politikacılar ve kamu görevlileri arasında algılanan yolsuzluğun derecesine göre sıralamaktadır. Yolsuzluk seviyesini tespit etmek amacıyla, her ülke için dörtten az olmamak şartıyla farklı sayıda kaynaktan toplanan anketler değerlendirilmektedir. $\mathrm{Bu}$ açıdan, YAE, anketlerin anketi olarak adlandırılan birleşik bir endekstir (Andvig vd., 2001).

\subsection{Lojistik Performans Endeksi}

Lojistik sadece ürünlerin, doğru zamanda, doğru yerden, doğru müşteriye, doğru miktarda taşınması ile sınırlı kalmayıp, hedeflenen müşteri hizmet düzeyini, en az maliyetle yakalayabilmektir. Zamanlama ve maliyetin bu kadar önemli olduğu bir sektörde lojistik hizmetlerin performansı önemlidir. Müşteri hizmet düzeylerinin belirlenmesi, stratejilerin oluşturulması, hedeflenen kalite düzeyinin yakalanması ve maliyetlerin minimize edilmesinin yönetilmesinde performans ölçümü kritik noktadır. 
Performans değerlendirmeleri, yöneticilerin stratejik kararlar vermelerinde etkili rol oynamaktadır. Dünya çapında büyük firmaların başarı faktörleri ele alındığında bunun arkasında ölçme ve değerlendirme sistemlerinin işlediği ve bunun sürekliliğinin sağlandığı gözlenmektedir. Kurumlar, müşteri hizmet düzeylerinde farklılık yaratabilmek ve rekabet avantajı sağlayabilmek için, lojistik yeteneklerini geliştirmeye ve fark yaratmaya çalışmaktadırlar. Geleneksel lojistik bakış açısı, böyle bir rekabet üstünlügünü sağlamakta ihtiyaç duyulan motivasyon ve beceriyi sağlayamamaktadır (Fawcett ve Cooper, 1998). Dolayısıyla, gelişmiş performans ölçüm sistemleri stratejik karar alabilmek için artık bir zorunluluk haline gelmiştir.

Performans ölçümünde kullanılan kriterlerin doğru belirlenmesi, teknik donanım ve araçların, kullanılan yöntemlerin doğru seçilmesi bilginin güvenilirliği açısından önemlidir. Performans ölçütleri, kapsamlı olması (sistemin bütün paydaşlarının dahil olması), nedensellik içermesi (geleceği etkileyecek kararları bugünün performanslarıyla değerlendirebilmesi), yatay entegrasyon (bütün departmanları ve işletmenin bütün fonksiyonlarının dahil olması) ve dikey entegrasyonlu olması (bütün karar vericileri ve firma stratejilerini içermesi), iç kıyaslama (performans ölçüm sistemlerinin farklı boyutlar arasında kırılma noktaları meydana geldiğinde kıyaslama yapabilmesi), fayda (performans ölçüm sistemlerinin karar vericiler tarafından kolaylıkla anlaşılabilir ve kullanılabilir olması) açısından değerlendirilebilir (Caplice ve Sheffi, 1995).

LPE nitel ve nicel ölçümlerin bir arada olması ile lojistik dostu ülkelerin profillerinin belirlenmesine yardımcı olmaktadır. Endeks, bir ülkenin tedarik zinciri boyunca lojistik performansını iki şekilde ölçmektedir. Bunlardan ilki Uluslararası Lojistik Performans Endeks, ikincisi de Yurtiçi Lojistik Performans Endeksidir.

Uluslararası Lojistik Performans Endeksi, lojistik uzmanlarının niteliksel değerlendirmelerini içeren anketlerden oluşmaktadır. LPE, ülkenin ticaret ve lojistik profilini 1 (en kötü) ile 5 (en iyi) arasında ölçeklendirmektedir. 1000'den fazla uluslararası nakliye acentesinde çalışan, 6000'den fazla lojistik profesyonelinin, en çok iş yapılan 8 ülkeyi değerlendirmesinin analiz edilmesi ile ülke derecelendirmesi yapılmaktadır. Her bir boyut için ayrı ülke puanı hesaplanmaktadır. Endeks altı farklı boyuttan oluşmaktadır. Bu boyutlar aşağıda belirtilmiştir. 
1. Gümrükler ve gümrük kontrol noktaları da dahil olmak üzere gümrükleme sürecinin etkinliği (hız, basitlik, formalitelerin öngörülebilirliği)

2. Ticaret ve ulaştırma altyapısının kalitesi (limanlar, demiryolları, bilgi teknolojileri)

3. Sevkiyatların rekabetçi fiyatlandırma ile ayarlanmasının kolaylığı

4. Lojistik hizmetlerinin yeterliliği ve kalitesi (taşıma organizatörleri ve gümrükçülerin)

5. Sevkiyatların izlenebilirliği ve takip edilebilirliği

6. Planlanan ve beklenen sürede sevkiyatların alıcıya ulaşma sıklığ

Bu çalışmada 2007, 2010, 2012, 2014, 2016 yıllarına ait Uluslararası Lojistik Performans Endeks verileri kullanılmıştır.

Literatürde yapılan birçok çalışmada Lojistik performans, lojistik performans endeksi ile ölçülmüştür. Lojistik Performans Endeksi (LPE), ülkelerin ticareti ve ulaştırmayı kolaylaştırıcılığını ölçümleyen en kapsamlı uluslararası karşılaştırma aracıdır (Ojala ve Çelebi, 2015). LPE ülkelerin gümrük, taşımacılık, altyapı gibi lojistik alanındaki performansların değerlendiren ve lojistik büyüme ile kaliteyi ölçen bir endekstir.

Founou (2002) lojistik yönetiminde bilişim teknolojileri kullanımının rekabete etkisini incelemiş, lojistik sektöründe bilgi teknolojilerinin kullanımının verimliliği ve rekabet gücünü arttırdığı sonucuna ulaşmıştır.

Babacan (2003), Türkiye'de lojistik sektörüne ilişkin durumu ve potansiyeli ele almıştır. Sektörde çalışan üst düzey yöneticilerle yapılan görüşmelerden, Türkiye'de özellikle son yıllarda sektöre verilen önemin arttığı, maliyetlerin azaltılma ve pazarın büyütülmesi gereği vurgulanmıştır.

Tutar ve diğ. (2009) ise, Türkiye ile Macaristan ve Romanya'nın lojistik sektörü gelişmişlik düzeyini kıyaslamışlar, Türkiye'nin her iki ülkeye göre de üstünlüğü olduğunu ve sözü edilen ülkeler arasında sıkı bir işbirliği bulunduğunu ifade etmişlerdir.

Ateş ve Işık (2010), Türkiye'de lojistik hizmetlerindeki gelişmelerin ihracat üzerine etkisini analiz etmişler, Granger nedensellik analizi sonucu, 
lojistik sektörü ile ihracat arasında çift yönlü nedensellik ilişkisini saptamışlardır.

Çekerol ve Kurnaz, (2011) küresel krizin lojistik sektörü üzerindeki etkilerini incelemişlerdir. Kriz ortamında ve sonrasında, maliyetlerini düşüren, bilgi altyapısını geliştiren ve kalifiye eleman ihtiyacını azaltan firmaların lojistik performanslarının artacağını ileri sürmüşlerdir.

Munim ve Schramm (2018) tarafından yapılan araştırmada liman altyapı kalitesinin yükseltilmesinin gelişmekte olan ülkelerde lojistik performansı iyileştirdiği ve sonuç olarakta ekonomik büyümeyi arttırdığı öne sürülmüştür.

Roy (2011), Kanada'nun Lojistik Performans Endeksi ve iş verimliliği arasındaki ilişkiyi analiz etmiş, iş verimliliği, ülkenin lojistik performansını ve tedarik zinciri yönetimini olumlu etkilediği sonucunu ortaya koymuştur.

Burmaoğlu (2012), tarafından yapılan çalışmada, AB ülkelerinde 2009 yılına ilişkin inovasyon göstergelerinin lojistik performansına etkisi analiz edilmiştir. Yapılan analiz sonucunda, insan kaynakları ve entelektüel varlıkların ülkelerin lojistik performansı üzerinde pozitif etkisi olduğu sonucuna ulaşılmıştır.

Sofyalıoğlu ve Kartal (2013)'ın yaptıkları çalışmada, Türkiye ile Avrasya ülkelerinin Lojistik Performans Endeksleri kıyaslanmış, Türkiye'nin lojistik faaliyetlerinde nispi üstünlügüne dikkat çekmişlerdir.

Puertas ve diğerleri 2005 ve 2010 yılları arasında 26 Avrupa birliği ülkelerinin ihracatında lojistiğin önemimin ithalatında olan öneminden daha fazla olduğu sonucunu çekim modelini kullanarak ortaya koymuşlardır (Puertas vd., 2013).

Mohan (2013) lojistik yönetimi ve rekabet gücü arasındaki ilişkiyi Hindistan örneği ile incelenmiştir. Hindistan'ın, lojistik performansını arttırabilmesi için öncelikle ulaştırma altyapısını geliştirmesi ve depolamaya önem vermesi gerekir sonucuna ulaşmıştır.

Sandberg ve Abrahamsson (2011) tarafından yapılan çalışmada da; sürdürülebilir rekabet gücü açısından lojistiğin önemi araştırılmış, lojistik faaliyetlerinin hem etkili hem de bilişim teknolojileriyle birlikte kullanımı sonucunda rekabet gücünü artacağ 1 ve daha sürdürülebilir olacağı sonucunu ortaya koymuşlardır. 
Bu çalışmada, lojistik performans Lojistik Performans Endeksi (LPE) ile ölçülmüştür.

\subsection{Küresel Rekabet Endeksi}

Bir ülkenin kurumlarının, politikalarının ve ülkenin verimlilik seviyesini belirleyen faktörlerin bir arada değerlendirilmesini rekabet olarak tanımlayabiliriz. Küresel rekabet ise doğrudan veya dolaylı olarak mal ve hizmet piyasasındaki işletmelerin, kurum ve kuruluşların faaliyetlerini etkileyen ortam ve şartlardan oluşmaktadır (Kantarc1, 2013).

Küresel Rekabet Endeksi (KRE) de ekonomik büyüme ve uzun dönemli refahın sürdürülebilir olması için, ülkeler arasında karşılaştırma olanağı sağlayan en kapsamlı değerlendirme araçlarındandır.

Endeks kurumlar, altyapı, makroekonomik istikrar, sağlık ve temel eğitim, mal piyasası etkinliği, finansal piyasanın gelişmişliği, teknolojik altyapı, piyasa büyüklüğü, faaliyet çeşitliliğ̈i, yenilik olmak üzere 12 farklı boyuttan meydana gelmektedir.

Araştırma enstitüleri ve önde gelen akademisyenlerin işbirliği ile üretilmiştir. Kullanıcılara çok sayıda sanayileşmiş ve gelişmekte olan ülke ekonomilerinin rekabet gücü göstergeleri hakkında kapsamlı bir veri kümesi sunmaktadır. 2007 yılı raporunda 125 ülke için, 2010 yılı raporunda 139 ülke, 2012 ve 2014 yılı raporunda 144 ülke için küresel rekabet sıralaması yapılmıştır. Sıralamalarda yer alan ülkeler dünya üzerindeki toplam yurtiçi gayri safi hasılanın yaklaşık \%98'ini oluşturmaktadır.

Literatüre bakıldığında küresel rekabet ile ilgili çalışmaların daha ekonometrik yaklaşımlar ile ortaya koyulduğu dikkat çekmektedir. Örneğin; Overbaugh (2013), gayrisafi milli hasıla, kültürel değişkenler ve küresel rekabet endeksi arasındaki ilişkiyi anlamlı bulmuştur (Overbaugh, 2013).

Salahodjaev ve Nazarov (2013) küresel rekabet endeksi ile insan kaynakları arasındaki ilişkiyi ekonometrik bir yaklaşım ile incelemişlerdir. Araştırmanın sonuçları beklenildiği gibi ortalama ömür ve temel eğitime yapılan yatırımların beşeri sermayeyi daha rekabetçi hale getirdiğini desteklemektedir. 
Ovalı (2014) çalışmasında, küresel rekabet gücü açısından Türkiye'nin konumu üzerine bir değerlendirme yapmıştır. Değerlendirme sonucunda, Türkiye'nin piyasa büyüklüğü, finansal piyasasının gelişmişliği ve mal piyasasının etkinliği alanlarında avantajlı olduğunu, buna karşın emek piyasasının etkinliği, makroekonomik istikrar, yükseköğrenim ve mesleki eğitim ile teknolojik hazırlık alanlarında ise dezavantajlı olduğu sonucuna ulaşmıştır.

Lechman ise küresel rekabette ürün ihracat kalıplarının değişmesini Ortadoğu Avrupa ülkeleri üzerine yaptığı araştırma ile ortaya koymuştur (Lechman, 2014).

Pena-Vinces ve Urbano (2015) Latin Amerika'da gelişmekte olan ülkeler için yaptıkları araştırmalarında ülkelerin, hükümet, üniversiteler ve araştırma merkezleri gibi kurum ve kuruluşlarının küçük ve orta ölçekli çokuluslu şirketlerin (SMNEs) uluslararası rekabet gücünü nasıl etkilediğini yapısal eşitlik yöntemi kullanarak değerlendirmişlerdir.

$\mathrm{Bu}$ çalışmada küresel rekabet ise, Küresel rekabet endeksi ile ölçülmüştür.

\subsection{Gayrisafi Yurtiçi Hasıla}

Gayrisafi yurt içi hasıla (GSYİH), bir ülkenin ekonomik büyüklüğünün belirten faktörlerden biridir. GSYİH, GSMH'den farklı olarak, belli bir dönem içinde, bir ülkenin ulusal sınırları içerisinde ister o ülke ekonomik birimleri olsun isterse yabancılar tarafından üretilmiş olsun, üretilen tüm nihai mal ve hizmetlerin para birimi cinsinden değeridir.

$\mathrm{Bu}$ çalışmada, ülkelerin ekonomik büyüklükleri, o yıllara ait yıllık GSYİH rakamları ile ölçülmüştür.

\section{Hipotez Geliştirme}

\subsection{Yolsuzluk Algısı ile Gayrisafi Yurt İçi Hasıla Arasındaki İlişkide Lojistik Performans ve Küresel Rekabetin Aracı Rolü}

Literatürde yolsuzluk algısı ile ekonomik büyüklük arasında ilişki ortaya atan çalışmalar bulunmaktadır. Tanzi ve Davoodi (1998) yolsuzluğun, toplum üzerinde sosyal, siyasal, sosyolojik, ahlaki etkileri olduğu gibi, 
ülkelerin makroekonomik performansları üzerinde de etkisi bulunduğunu ifade etmişlerdir (Tanzi ve Davoodi, 1998).

Wright ve diğerleri (2013) ise yolsuzluk algısı ile ekonomik büyüme arasındaki ilişkiyi lineer ve lineer olmayan panel nedensellik testi ile incelemiş ve bu iki değişken arasında istatistiksel olarak anlamlı bir ilişki olduğu sonucuna ulaşmışlardır (Wright ve Craigwell, 2013).

Literatürdeki çalışmalara göre yolsuzluk algısı ile ekonomik büyüme arasında bir ilişki olduğu belirtilebilir.

H1: Yolsuzluk algısı ile Gayrisafi Yurt İçi Hasıla arasındaki ilişkide Lojistik performans ve küresel rekabetin aracı rolü bulunmaktadır.

\subsection{Yolsuzluk Algısı ve Lojistik Performans İlişkisi}

Literatürde yolsuzluk algısı ile lojistik performans arasındaki bir ilişki olduğunu açıklayan çalışmalar bulunmaktadır. Örneğin; Omran (2012) yolsuzluk ile lojistik performans arasında bir ilişki olduğunu iddia etmiştir. Araştırma örnekleminde bulunan 19 ülkeyi yolsuzluk algı endeksine göre yüksek ve düşük şeffaf olarak ikiye ayırmış ve bunlarla lojistik performans arasındaki ilişkiyi ortaya koymuştur. Buna göre şeffaflık seviyesi yüksek olan ülkelerde, şeffaflık ile gümrükleme sürecinin etkinliği, altyapının kalitesi, sevkiyatların kolaylığı ve planlanan sürede sevkiyatların alıcıya ulaşma sıklığı boyutları arasında istatistiksel olarak daha anlamlı sonuçlar ortaya çıkmıştır (Omran, 2012).

Murphy ve Daley (1999) lojistik dostu kavramını tanımlamışlardır. Uluslararası yükleme operasyonlarının düzenlenmesi kolaylığı, lojistik dostu ülke olmayı, Uluslararası yükleme operasyonlarının düzenlenmesinin zor olması, lojistik dostu olmayan ülkeyi tanımlamaktadır.

Ojala ve Queiroz (2002) Dünya Bankası için yaptıkları çalışmalarında, yolsuzluk algısı ile lojistik dostu olmak arasında yüksek bir korelasyon olduğunu ve bunun düşük yolsuzluk algısına sahip olan bir ülkede ticaret ve lojistik uygulamalarının daha kolay yapılabileceğinin bir göstergesi olduğunu ortaya koymuşlardır.

Literatürdeki çalışmalara göre yolsuzluk algisı ile lojistik performans arasında bir ilişki olduğu belirtilebilir. 
H2: Yolsuzluk algısı lojistik performansı pozitif yönde etkiler.

\subsection{Yolsuzluk Algısı ve Küresel Rekabet İlişkisi}

Literatürde yolsuzluk algısı ile küresel rekabet arasında ilişki olduğunu açıklayan çalışmalar bulunmaktadır. Örneğin Buckley ve Casson (1998) küresel rekabetin bir ülkenin uluslararası pazarlarda rekabet avantajı yaratmasıyla ilişkilendirmişlerdir. Bir ülkedeki yolsuzluk algısının yüksek olmasının şirketlerin o ülke pazarına girme kararları üzerinde olumsuz etkisi olduğunu iddia etmişlerdir (Buckley ve Casson, 1998).

Alas ve Miller 2009 yılında yaptığı çalışmada küresel şirketlerin $\% 45$ 'inin yolsuzluk riskinden dolayı ülke pazarlarına girmekten çekindiklerini ortaya koymuştur (Alas ve Miller, 2009).

$\mathrm{Bu}$ çalışmalar dikkate alındığında yolsuzluk algısı ile küresel rekabet arasında bir ilişki olduğu belirtilebilir.

H3: Yolsuzluk algısı küresel rekabeti pozitif yönde etkiler.

\subsection{Lojistik Performans, Küresel Rekabet ve Gayrisafi Yurt İçi Hasıla İlişkisi}

Literatürde Lojistik Performans, Küresel Rekabet ve Gayrisafi Yurt İçi Hasıla arasındaki ilişkileri araştıran çalışmalar da yer almaktadır. Örneğin, Hu ve diğerleri lojistik altyapısına yapılan yatırımlar ile GSYH arasında Granger nedensellik testi uygulayarak anlamlı bir ilişki bulmuşladır (Hu vd., 2012).

Güneş, küresel rekabet endeksini kullandığı araştırmasında ülkelerin büyüme oranlarına rekabetçiliğin pozitif katkı sağladığını panel data analizi kullanarak ortaya koymuştur (Güneş, 2012).

Erkan (2014) ise çalışmasında, Küresel Rekabet Endeksi bileşenleri ile Lojistik performans endeksi bileşenleri arasındaki ilişkiyi doğrusal regresyon ile incelemiş, küresel rekabet ile lojistik performans arasındaki ilişkiyi ortaya koymuştur.

H4: Küresel rekabet Gayrisafi Yurt İçi Hasılayı pozitif yönde etkiler. 
H5: Lojistik performans Gayrisafi Yurt İçi Hasılayı pozitif yönde etkiler.

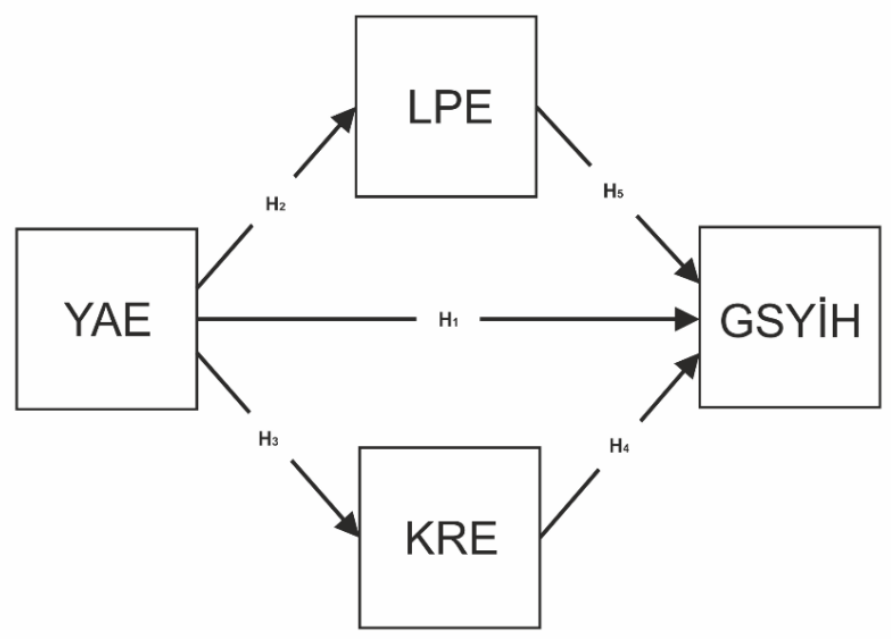

Şekil 1. Araştırma Modeli

\section{Araştırma Yöntemi}

Bu araştırmada yolsuzluk algısı ile Gayrisafi Yurt İçi Hasıla arasındaki ilişkide lojistik performansın ve küresel rekabetin birlikte ara değişken rollerinin analiz edilmesi için yapısal eşitlik modeli yöntemi kullanılmıştır. Yapısal eşitlik modeli yöntemi çok değişkenli bir analiz yöntemi olup kavramsal modeli oluşturan hipotezlerin bir arada test edilmesine olanak vermektedir. Bu nedenle de iki değişkenin aynı anda ara değişken rolünün ölçülebilmesi için en uygun yöntemdir. Ayrıca bu yöntem, doğrudan ve dolaylı ilişkilerin tek bir model içerisinde ölçülebilmesine olanak sağlamaktadır (Meydan ve Şeşen, 2011: 5). Yapısal eşitlik modeli yöntemi geleneksel yöntemlerle karşılaştırıldığında ölçüm hatalarını en aza indiren yöntemdir (Byrne, 2010; Fornell ve Larcker, 1981).

Yapısal eşitlik modeli yönteminde, aynı anda iki ara değişkenin bağımlı ve bağımsız değişken arasındaki ilişkide ara değişken rolünün ortaya konulması için 3 ayrı model geliştirilir. Bunun nedeni, bağıml, bağımsız ve ara değişkenler arasındaki beklenen etkileri ayrıştırmaktır. 1 . Modelde bağımlı ve bağımsız değişken arasındaki direk etki ölçülür. 2 . 
Modelde bağımsız değişken ile ara değişkenler arasındaki etkiler ölçülür. 3. Modelde de kavramsal modelin tüm değişkenleri arasındaki etkiler aynı anda ölçülür. Tüm modellerde Yapısal eşitlik modeli yönteminde iyi uyum değerleri dikkate alınır. Kavramsal modelden türetilen 3 ayrı modeldeki yol analizi katsayılarının standardize değerleri birbirleri ile karşılaştırılır. Karşılaştırma yapılırken, bağımlı değişken ile bağımsız değişken arasındaki anlamlı ilişkinin, ara değişkenler modele katıldığında ilişkinin anlamsıza dönüşüp dönüşmediğine ya da anlamlı olsa bile ilişkinin yönüne bakılır (Civelek, 2018).

\section{Araştırmanın Örneklemi}

Araştırmanın örneklemi 88 ülkenin 5 yıllık (2007, 2010, 2012, 2014, 2016) endeks değerlerinden oluşmaktadır. Bu endeksler sırasıyla Yolsuzluk Alg1 Endeksi, Lojistik Performans Endeksi, Küresel Rekabet Endeksi ile Gayrisafi Yurt İçi Hasıla rakamlarıdır. LPI iki yılda bir yayınlanan bir endeks olduğundan çalışmada kullanılan diğer endeksler içinde LPI'ın yayınlandığı yıllar baz alınmıştır. Araştırmanın kapsamı yukarıda belirtilen yıllarda endeks değerlerinde eksik olmayan 88 ülkedir. Yolsuzluk Algı Endeksi verileri Uluslararası Şeffaflık Örgütü (CPI) tarafından her yıl yayınlanmaktadır. YAE ile ilgili araştırmaya konu olan veriler Uluslararası Şeffaflık Örgütü'nden alınmıştır. Lojistik Performans Endeksi verileri Dünya Bankası'nın iki yılda bir yayınladığı LPI Raporlarından alınmıştır. Küresel Rekabet Endeksi verileri Dünya Ekonomik Forumu (WEF) Raporundan alınmıştır. Gayrisafi Yurt İçi Hasıla verileri Dünya Bankası'ndan alınmıştır.

\section{Analiz Sonuçları}

Modeller ile veri arasındaki uyum literatürde en çok kullanılan uyum indeksleri olan CMIN/DF, CFI (the comparative fit index), IFI (the incremental fit index), RMSA (the root-mean-square error of approximation) ile değerlendirilmiştir (Akgün vd., 2014).

CFI uyum indeksi, artımsal bir uyum istatistiğidir. Bu indeks doymuş modellerin karşılaştırmaları ve parametreleri arasında her hangi bir ilişki olmadığında bağımsız modeli kullanarak test edilir. CFI uyum indeksi 0 
ile 1 arasında değerler alır. 0.90'dan büyük değerler iyi uyum olduğunu gösterir (Bayram, 2010).

Ara değişkenlerin rollerini test etmeden önce kavramsal modelde yer alan tüm değişkenlerin arasındaki korelasyona bakılır. Ara değişken analizinin ön şartı tüm değişkenler arasında anlamlı ilişki bulunmasıdır (Baron ve Kenny, 1986). Tablo 1'de kavramsal modelde yer alan değişkenler arasında anlamlı ilişki olduğu görülmektedir.

Tablo 1. Korelasyon Katsayılan

\begin{tabular}{cl|cccc}
\hline \multicolumn{2}{l|}{ Değişkenler } & $\mathbf{1}$ & $\mathbf{2}$ & $\mathbf{3}$ & $\mathbf{4}$ \\
\hline 1. & YAE & - & & & \\
2. & KRE & $0.883^{*}$ & - & & \\
3. & LPE & $0.861^{*}$ & $0.928^{*}$ & - & - \\
4. & GSYİH & $0.430^{*}$ & $0.653^{*}$ & $0.703^{*}$ & \\
\hline
\end{tabular}

${ }^{*} \mathrm{p}<0.01$.

Ara değişken rolünün test edilmesinde kullanılan 3 model sırasıyla Şekil 2, Şekil 3 ve Şekil 4'de görüldüğü gibidir.

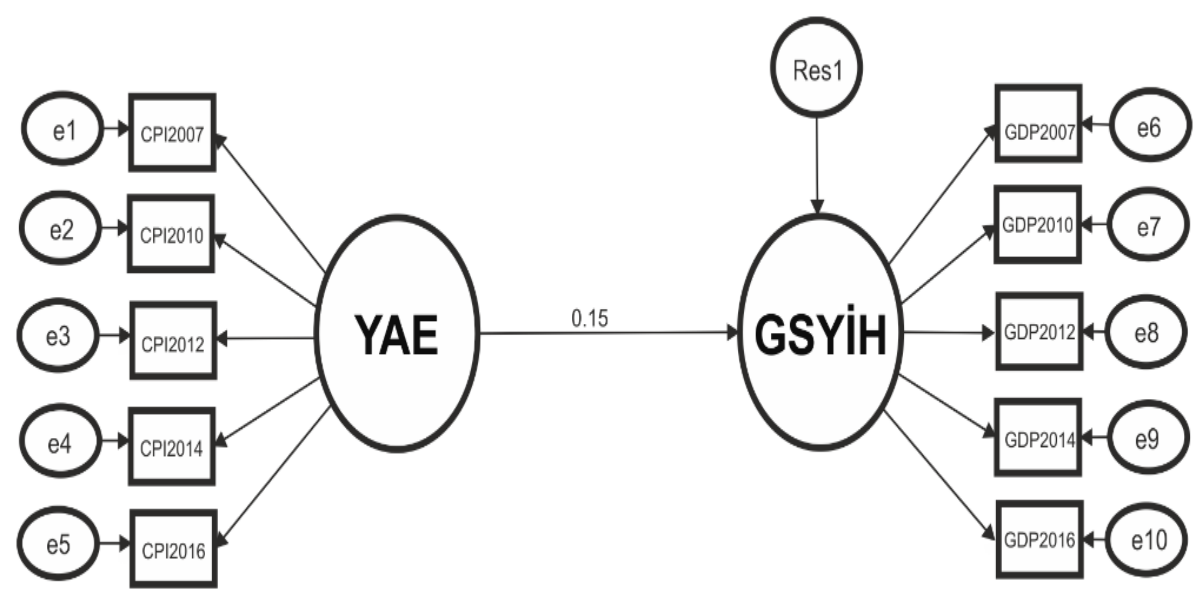

Not: $\chi 2 / D F=2.554, C F I=0.985, I F I=0.985, R M S E A=0.134$

Şekil 2. Model 1'in Yol Analizi 
Şekil 2'de Model 1'in yol analizi sonuçları görülmektedir. Model 1'de bağımlı değişken ile bağımsız değişken arasındaki direk ilişki ölçülmüştür. İlişki anlamlı ve pozitif yönlüdür. Modelin uyum indeksleri literatürde kabul gören sınırlar içerisindedir. Modelin uyum indekslerinin değerleri sirasiyla $\chi 2 / \mathrm{DF}=2.554, \mathrm{CFI}=0.985, \mathrm{IFI}=0.985, \mathrm{RMSEA}=0.134$ olarak bulunmuştur.

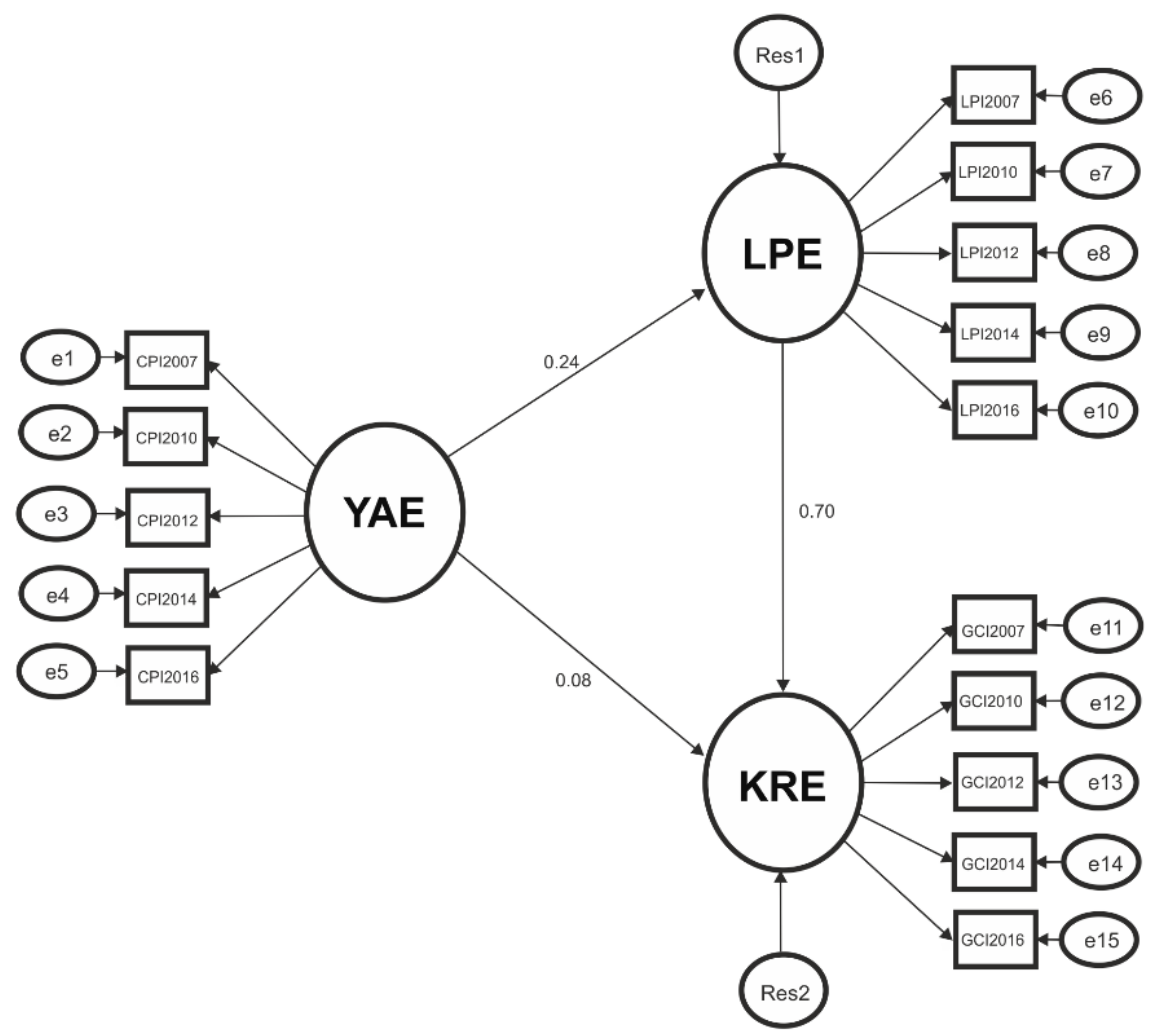

Şekil 3. Model 2'nin Yol Analizi

Şekil 3'de Model 2'nin yol analizi sonuçları görülmektedir. Model 2'de bağımsız değişken ile ara değişkenler arasındaki direk ilişkiler ölçülmüştür. İlişkiler anlamlı ve pozitif yönlüdür. Modelin uyum indeksleri literatürde kabul gören sınırlar içerisindedir. Modelin uyum indekslerinin 
değerleri sırasıyla $\chi 2 / \mathrm{DF}=2.921, \mathrm{CFI}=0.954, \mathrm{IFI}=0.954, \mathrm{RMSEA}=0.149$ olarak bulunmuştur.

Şekil 4'de Model 3'nin yol analizi sonuçları görülmektedir. Model 3'de araştırmanın kavramsal modeli ölçülmüştür. Modelin uyum indeksleri literatürde kabul gören sınırlar içerisindedir. Modelin uyum indekslerinin değerleri sirasiyla $\chi 2 / \mathrm{DF}=2.856, \mathrm{CFI}=0.947, \mathrm{IFI}=0.947, \mathrm{RMSEA}=0.146$ olarak bulunmuştur.

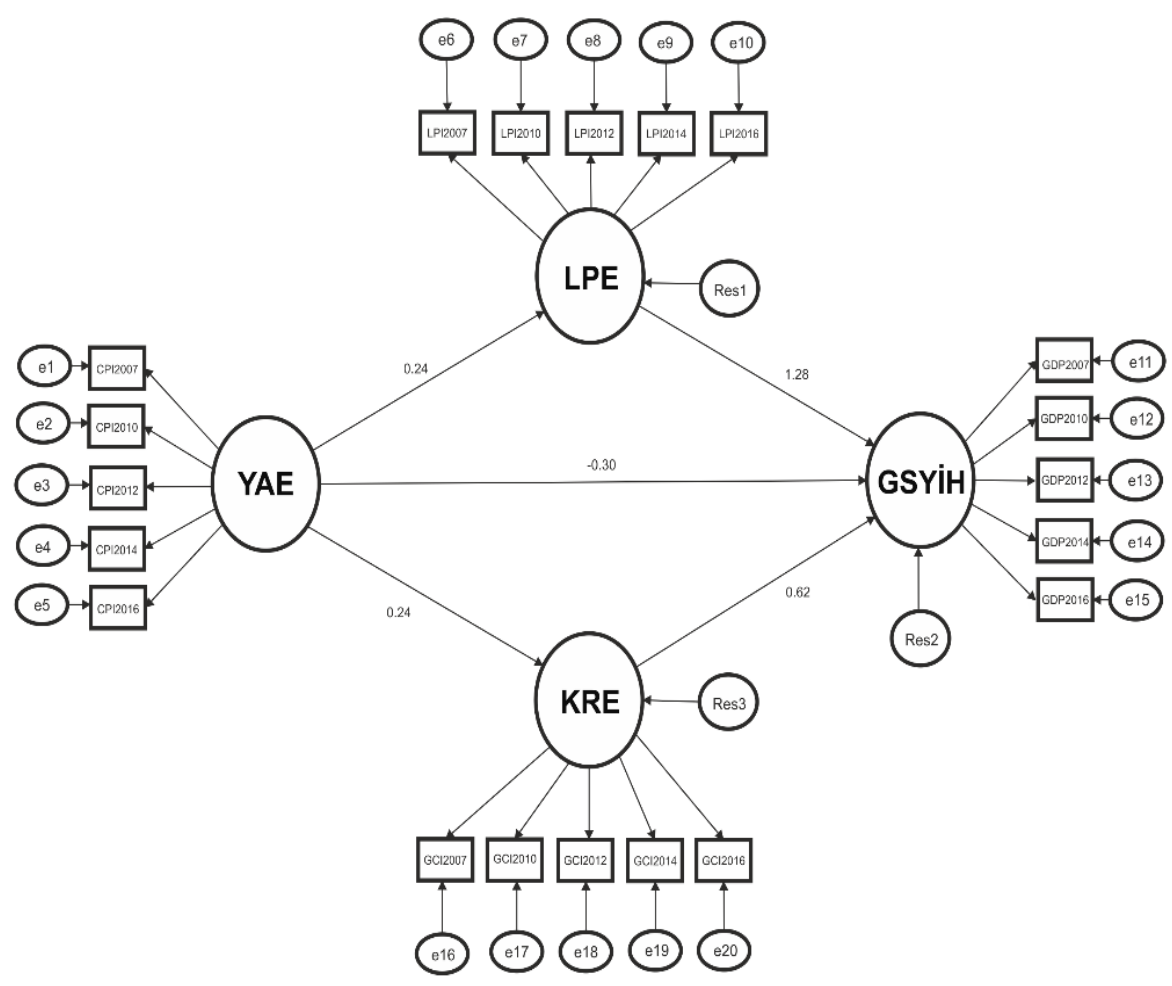

Not: $\chi 2 / D F=2.856, C F I=0.947, I F I=0.947, R M S E A=0.146$

Şekil 4. Model 3'in Yol Analizi

Kavramsal modelde yer alan hipotezlerin her 3 modelde ortaya çıan test sonuçları Tablo 2' de özetlenmiştir. 
Tablo 2. Hipotez Sonuçları

\begin{tabular}{|c|c|c|c|}
\hline İlişkiler & Model 1 & Model 2 & Model 3 \\
\hline YAE $\rightarrow$ GSYİH $\left(\mathrm{H}_{1}\right)$ & $0.414^{*}$ & & $-0.935^{*}$ \\
\hline $\mathrm{YAE} \rightarrow \mathrm{LPE} \quad\left(\mathrm{H}_{2}\right)$ & & $0.863^{*}$ & $0.865^{*}$ \\
\hline $\mathrm{YAE} \rightarrow \mathrm{KRE} \quad\left(\mathrm{H}_{3}\right)$ & & $0.279^{*}$ & $0.870^{*}$ \\
\hline $\mathrm{KRE} \rightarrow \mathrm{GSYİH}\left(\mathrm{H}_{4}\right)$ & & & $0.532^{*}$ \\
\hline LPE $\rightarrow$ GSYİH $\left(\mathrm{H}_{5}\right)$ & & & $1.070^{*}$ \\
\hline Model Uyum İndeksleri & $\begin{array}{l}\chi 2 / \mathrm{df}=2.554, \\
\text { CFI=0.985, } \\
\text { IFI=0.985, } \\
\text { RMSEA }=0.134\end{array}$ & $\begin{array}{l}\chi 2 / \mathrm{df}=2.921, \\
\mathrm{CFI}=0.954, \\
\mathrm{IFI}=0.954, \\
\text { RMSEA }=0.149\end{array}$ & $\begin{array}{l}\chi 2 / \mathrm{df}=2.856, \\
\mathrm{CFI}=0.947, \\
\mathrm{IFI}=0.947, \\
\text { RMSEA }=0.146\end{array}$ \\
\hline
\end{tabular}

Not: Yol analizi katsayıları standardize edilmiştir.

${ }^{*} \mathrm{p}<0.01$

\section{Sonuç ve Değerlendirmeler}

$\mathrm{Bu}$ araştırmada 3 adet model test edilmiş olup hipotez testleri sonucunda H2, H3, H4 ve H5 hipotezleri kabul edilmiştir. Bulgular literatürdeki sonuçlarla uyumludur. H1 hipotezi 1. Modelde kabul edilmiş 3. Modelde ise ilişki negatif yöne döndügünden reddedilmiştir. Bu sonuç YAE ile GSYİH arasındaki ilişkide LPE ve KRE' nin ara değişken rolü olduğunu istatistiksel olarak doğrulamaktadır. Bu araştırmanın en önemli sonucu, bir ülkenin lojistik performansı arttırılırken eş zamanlı olarak yolsuzlukla mücadele edilmesi ve küresel rekabette iyileştirici önlemler alınması gerektiğini ortaya koymasıdır.

\subsection{Teorik Katkıları}

$\mathrm{Bu}$ sonucun teorik katkısı olarak literatürde LPE konusunda yer alan çalışmalara yol gösterici olacağı ön görülmektedir. Literatürde LPE ile ilgili henüz çok çalışma bulunmamaktadır. Bu çalışma ilk olarak YAE ve GSYİH ilişkisinde LPE ve KRE endekslerinin rolünü ortaya koyması açısından önemlidir. 


\subsection{Yönetimsel Katkıları}

Bu çalışmanın yönetimsel katkısı, ülkemizde lojistik alanında yapılan yatırımlarım geri dönüşünün ve ülke ekonomisine katkısının nasıl arttırılabileceği konusunda yeni bir bakış açısı getirmesidir. Bilindiği üzere ülkemizde son yıllarda lojistik ve ulaştırma alanında ciddi yatırımlar yapılmış ve yapılmaya devam etmektedir. Türkiye'nin LPE endeksi değeri 2007 yılında 3,15 olarak hesaplanmıştır. Bu değer 2016 yılında 3,42 olarak hesaplanmıştır. Türkiye'nin yolsuzluk algısı endeksi değeri 2007 yılında ve 2016 yılında 4,10 olarak bulunmuştur. Bu yıllar arasında Türkiye'nin yolsuzluk algısında değişiklik olmamıştır. Aynı yıllar arasında küresel rekabet endeksinde ise 4,25'den 4,39'a bir artış olmaktadır.

$\mathrm{Bu}$ araştırma lojistik alanında yapılan yatırımların ülke ekonomisine faydasının arttırılması için yapılabilecekler konusunda ışık tutmaktadır. $\mathrm{Bu}$ araştırmanın sonuçlarına göre bir ülkenin lojistik performansını artırıcı yatırımlar yapılırken eş zamanlı olarak yolsuzlukla mücadele edilmesi ve küresel rekabette iyileştirici önlemler alınması gerekmektedir. Dolayısıyla Türkiye'nin YAE, KRE ve LPE değerlerinde eş zamanlı olarak iyileşme olması ülke büyümesinde en iyi sonucun alınmasını sağlayacaktır.

\subsection{Kısıtlar ve İleri Araştırmalar}

Bu araştırmada 5 yıllık $(2007,2010,2012,2014,2016)$ endeks değerlerinden faydalanılmıştır. Araştırmanın analizlerinin yapıldığı tarih itibariyle bazı endekslerin 2018 verileri yayınlanmamış olduğundan, 2018 verileri araştırmaya dahil edilememiştir. Bu araştırmada YAE ile GSYİH arasındaki ilişkide LPE ve KRE' nin ara değişken rolü olduğunu istatistiksel olarak anlamlı bulunmuştur. İleriki araştırmalarda bu modele farklı boyutlar eklenerek model geliştirilebilir ve yeni ilişki hipotezleri geliştirilebilir. Özellikle bir ülkenin ekonomik büyümesinin bu modelde yer alan boyutlar ile ilişkisi ileriki araştırmalarda dikkate alınmak suretiyle kapsamlı modeller oluşturulabilir. 
EXTENDED ABSTRACT

\title{
Mediator Role of Logistics Performance and Global Competition in Relationship between Corruption Perception and Gross Domestic Product: Evaluation of Turkey \\ *
}

\author{
Nagehan Uca - Mustafa Emre Civelek - Murat Çemberci \\ Istanbul Commerce University - Yaldiz Technical University
}

The aim of this research is to clarify the mediator role of logistic performance and global competition in relationship between corruption perception and gross domestic product. In the literature there are some studies showing that there are other factors besides logistic performance that have effects on GDP. In some of these studies, corruption perception has been found to be influential on both logistic performance and GDP. In this study, a model that evaluates logistics performance together with corruption perception and global competition index is proposed. According to the analysis results, it has been found statistically significant that logistics performance and global competition play mediator role at the same time in the relation between corruption perception and GDP. According to these results, Turkey evaluation has been made.

In this study, the structural equation modeling method was used to analyze the mediator roles of logistic performance and global competition in the relationship between corruption perception and Gross Domestic Product. The structural equation modeling is a multivariate analysis method and allows the hypotheses of the conceptual model to be tested together. For this reason, it is the most appropriate method to measure the mediator role of two variables simultaneously. In addition, this method allows direct and indirect relationships to be measured in a single model (Meydan ve Şeşen, 2011: 5). Structural equation modeling is a method that minimizes measurement errors compared to traditional methods (Byrne, 2010; Fornell ve Larcker, 1981). 
In the method of structural equation model, 3 different models are developed to reveal the mediator role of the two variables at the same time in the relationship between dependent and independent variables. The reason for this is to differentiate the expected effects between dependent, independent and mediator variables. The direct effect is measured between the dependent and independent variable in the first model. In the second model, the effects between the independent variables and the intermediate variables are measured. In the third model, the effects between all variables of the conceptual model are measured simultaneously. In all models, good fit values are taken into account in the method of structural equation model. The standardized values of the path analysis coefficients in 3 different models derived from the conceptual model are compared with each other. In comparison, the significant relationship between the dependent variable and the independent variable is observed at whether the relationship becomes insignificant when the mediator variables are included in the model or the direction of the relationship even if it is significant (Civelek, 2018).

The sample of the study consists of the index values of 88 countries in 5 years $(2007,2010,2012,2014,2016)$. These indices are respectively Corruption Perception Index, Logistics Performance Index, Global Competitiveness Index and Gross Domestic Product figures. Since LPI is an index published every two years, the other indices used in the study are based on the years in which the LPI was published. The scope of the research is 88 countries which are not missing index values in the years mentioned above. Corruption Perception Index data is published annually by Transparency International (CPI). The data on CPI were taken from Transparency International. The data of the Logistics Performance Index are taken from the LPI Reports published by the World Bank every two years. Global Competitiveness Index data are taken from the World Economic Forum (WEF) Report. The data of Gross Domestic Product are taken from the World Bank.

In this study, 3 models were tested and at the end of the hypothesis tests, the hypotheses $\mathrm{H} 2, \mathrm{H} 3, \mathrm{H} 4$ and $\mathrm{H} 5$ were accepted. The findings are consistent with the results in the literature. The hypothesis H1 was rejected in the third model, which was accepted in model 1, because the relationship turned negative. This result statistically confirms the mediator 
role of LPI and GCI in the relationship between CPI and GDP. The most important result of this research is to increase the logistics performance of a country and to conclude that it is necessary to combat corruption and to take remedial measures in global competition. As the theoretical contribution of this result, it is foreseen that it will guide the studies on LPI in the literature. There are not many studies on LPI in the literature. This study is important in terms of revealing the role of LPI and GCI indices in CPI and GDP relationship.

The managerial implication of this study is to bring a new perspective on how to return the investments made in the field of logistics in our country and to increase its contribution to the national economy. As it is known, significant investments in logistics and transportation area have been made and continue to be made in our country in recent years. Turkey LP index value is calculated as 3.15 in 2007. This value is calculated as 3.42 in 2016. Turkey's corruption perception index value was found to be 4.10 in 2016 and 2007. Among this year's was no change in Turkey's corruption perception. In the same years, the global competition index increased from 4.25 to 4.39 .

This research sheds light on what can be done to increase the benefits of investments in the logistics sector to the national economy. According to the results of this research, it is necessary to combat corruption and to take remedial measures in global competition while making investments to increase the logistics performance of a country. Thus, the CPI Turkey, simultaneously an improvement in GCI and LPI values will ensure the best results in the country's growth.

In this research, the index values of 5 years $(2007,2010,2012,2014$, 2016) were used. Since 2018 data of some indices as of the date of analysis of the research were not published, 2018 data could not be included in the study. In this study, it was found statistically significant that LPI and GCI were interrelated in the relationship between CPI and GDP. In future research, models can be developed by adding different dimensions to this model and new relationship hypotheses can be developed. Particularly, the relationship between the economic growth of a country and the dimensions in this model can be taken into account in the future. 


\section{Kaynakça / References}

Akgün, A. E., Ince, H., Imamoğlu, S.Z., Keskin, H., ve Kocoğlu, I. (2014). The mediator role of learning capability and business innovativeness between total quality management and financial performance. International Journal of Production Research, 52(3), 888-901.

Akıncl, M., Erkal, G., ve Yılmaz, Ö. (2015). Ekonomik özgürlükler ve yolsuzluk ilişkisi : Türkiye için bir zaman serisi analizi. HAK-IŞ Uluslararası Emek ve Toplum Dergisi, 4(8), 144-165.

Akkuş, M. (2014). Türkiye'de yolsuzluk bibliyografyası. İş ahlakı dergisi, 3(2), 180-194.

Alas, A. M., ve Miller, F. (2009). Corruption crackdown. Price water housecoopers.

Andersson, P., Aronsson, H., ve Storhagen, N. G. (1989). Measuring logistics performance. Engineering Costs and Production Economics, 17(14), 253-262.

Andvig, J., Fjelsatd, O.-H., Amundsen, I., Sissener, T., ve Soreide, T. (2001). Corruption: A review of contemporary research. Chr. Michelsen Institute Report(7).

Arvis, J. F., Mustra, M. A., Ojala, L., Stepherd, B., ve Saslavsky, D. (2012). Connecting to compete 2012: Trade logistics in the global economy. Washington: World Bank.

Ateş, İ., ve Işık, E. (2010). Türkiye'de lojistik hizmetlerinin gelişiminin ihracattaki büyümeyi etkiler. Ekonomi Bilimleri Dergisi, 1(2), 99-106.

Bayram, N. (2010). Yapısal eşitlik modellemesine giriş: AMOS uygulamaları. Bursa: Ezgi Kitabevi.

Byrne, B.M. (2010). Structural equation modeling with AMOS: Basic concepts, applications, and programming. 2nd Ed. New York: Routledge Taylor ve Francis Group.

Babacan, M. (2003). Lojistik sektörünün ülkemizdeki gelişimi ve rekabet vizyonu. Ege Akademik Bakış, 1(3), 8-15.

Baron, R., ve Kenny, D. (1986). The moderator - mediator variable distinction in social phychological research: Conceptual, strategic and statistical consideration. Journal of Personality and Social Phychology, 51(6), 1173-1182. 
Buckley, P. J., ve Casson, M. C. (1998). Models of the multinational. Journal of International Business Studies, 29(1), 21-44.

Burmaoğlu, S. (2012). Ulusal inovasyon göstergeleri ile ulusal lojistik performansı arasında ilişki: $\mathrm{AB}$ ülkeleri üzerine bir araştırma . Ege Akademik Bakış, 12(2), 193-208.

Caplice, C., ve Sheffi, Y. (1995). A review and evaluation of logistics performance measurement system . The International Journal of Logistics Management, 6(1), 71-87.

Civelek, M. (2018). Yapısal eşitlik modellemesi metodolojisi. İstanbul: Beta.

Civelek, M. E., Uca, N., ve Çemberci, M. (2015). The mediator effect of logistics performance index on the relation between global competitiveness index and gross domestic product. European Scientific Journal, 11(13), 368-375.

Çekerol, G., ve N., K. (2011). Küresel kriz ekseninde lojistik sektörü ve rekabet analizi. Selçuk Üniversitesi Sosyal Bilimler Enstitüsü Dergisi, (25), 47-59.

Çelebi, Ü., Civelek, M. E., ve Çemberci, M. (2015). The mediator effect of foreign direct investments on the relation between logistics performance and economic growth. Journal of Global Strategic Management, 9(1), 17-21.

Çemberci, M., Civelek, M., E., Canbolat, N. (2015). The moderator effect of global competitiveness index on dimensions of logistics performance index. World Conference on Technology, Innovation and Entrepreneurship. Procedia - Social and Behavioral Sciences, 195, 1514 1524.

D'Aleo, V., ve Sergi, B. (2017). Does logistics influence economic growth? The European Experience. Management Decision, 55(8), 1613-1628.

Dökmen, G. (2012). Yolsuzlukların vergi gelirleri üzerine etkisi: Dinamik panel veri analizi. Doğus Üniveristesi Dergisi, 13(1), 41-51.

Esfahani, H. S., ve Ramirez, M. (2003). Institutions, infrastructure, and economic growth. Journal of Development Economics, 70, 443-477.

Ekici, Ş. Ö., Kabak, Ö., ve Ülengin, F. (2016). Linking to compete: Logistics and global competitiveness interaction. Transport Policy, 48(1), 117-128.

Erkan, D. D. (2014). Türkiye'de lojistik sektörü ve rekabet gücü. Assam Uluslararası Hakemli Dergi, 1, 44-65. 
Fawcett, S. E., ve Cooper, M. (1998). Logistics performance measurement and customer success. Industrial Marketing Management, 27 (4), 341357.

Fernandez, M. G., ve Velasco, C. G. (2014). Shadow economy, corruption and public debt in Spain. Journal of Policy Modeling, 36, 1101-1117.

Fornell, C., ve Larcker, D. F. (1981). Evaluating structural equation models with unobservable variables and measurement error. Journal of Marketing Research, 18(1), 39-50.

Founou, R. (2002). The role of IT in logistics competitive advantage or strategic necessity? 2nd Swiss Transport Research Conference, (s. 1-21).

Güneş, S. (2012). Rekabet düzeyi ile büyüme arasındaki ilişki: Panel analizi. Finansal Araştırmalar ve Çalışmalar Dergisi, 3(7), 43-54.

Güney, T. (2013). Yolsuzluk ve refah. Yayımlanmamış Doktora Tezi, Dumlupınar Üniversitesi, Sosyal Bilimler Enstitüsü, Kütahya.

Hu, K., Gan, X. ve Gao, K. (2012). Co-integration model of logistics infrastructure investment and regional economic growth in central China. 2012 International Conference on Medical Physics and Biomedical Engineering (s. 1036-1041). Physics Procedia.

Kantarc1, M. (2013). ÜSIMMP 2013 VI. Ulusal kongresi. 04 04, 2016 tarihinde Teknoloji Transferi: http://www.teknolojitransferi.gov.tr/ adresinden alındı

Kaufmann, D. (1997, 01 01). corruption: the facts. Foreign Policy, s. 114131.

Klitgaard, R. (1988). Controlling corruption. Berkeley: University of California Press.

Lechman, E. (2014). Changing patterns in the export of goods versus international competitiveness. A comparative analysis for centraleast european countries in the period 2000-2011. Comparative Economic Research, 17(2), 62-77.

Marti, L., Martin, J., ve Puertas, R. (2017, Mayıs). A DEA - Logistics performance index. Journal of Applied Economics, 20(1), 169-192.

Meydan, C. H., ve Şeşen, H. (2011). Yapısal eşitlik modellemesi AMOS uygulamaları. ANKARA: Detay Yayıncilik.

Mohan, C. (2013). The impact of logistic management on global competitiveness. International Journal of Business and Management Invention, 2(3), 39-42. 
Morse, S. (2006). Is corruption bad for environmental sustainability? a cross-national analysis. Ecology and Society, 11(1), http://www.ecologyandsociety.org/vol11/iss1/art22/ adresinden 07.01.2019 tarhinde erişilmiştir.

Munim, Z. H., Schramm, H. J. (2018). The impacts of port infrastructure and logistics performance on economic growth: The mediating role of seaborne Trade. Journal of Shipping and Trade, 3(1), 1-19.

Murphy, P., ve Daley, R. (1999). Revisiting logistical friendliness: Perspectives of international freight forwarders. Journal of Transportation Management, 65-71.

Müsiad. (2013). Lojistik sektör raporu. İstanbul: Müsiad.

Ojala, L., ve Çelebi, D. (2015). The World Bank's Logistics Performance Index (LPI) and drivers of logistics performance. OECD.

Ojala, L., ve Queiroz, C. (2002). Logistics friendliness, GDP and the perceived level of corruption of countiries. LRN Conference (s. 211-216). Birmingham: The Institute of Logistics and Transport .

Omran, M. F. (2012). Uncovering the relationship between the degree of transparency and the level of trade logistics in the Middle East and North Africa. African Journal of Economic and Sustainable Development, 1(4), 377.

Ovalı, S. (2014). Küresel rekabet gücü açısından Türkiye'nin konumu üzerine bir değerlendirme. Uluslararası İktisadi ve İdari İncelemeler Dergisi, 13, 17-36

Overbaugh, S. N. (2013). National culture, country-level competitiveness, and economic development. International Journal of Business ve Economics Perspectives, 8(1), 93-109.

Özcan, B. (2012). OECD ülkelerinde yolsuzluğun ekonomik belirleyenlerini panel veri analizi yöntemi. İÜ İktisat Fakültesi Mecmuası, 62(2), 253-282.

Pena-Vinces, J. C., ve Urbano, D. (2015). The influence of domestic economic agents on the international competitiveness of latin american firms: Evidence from peruvian small and medium multinational enterprises. Emerging Markets Finance and Trade, 50(6), 228248. 
Puertas, R., Martı, L., ve Garcia, L. (2013). Logistics performance and export competitiveness: European experience. Springer Science+Business Media, 41(3), 467-480.

Roy, J. (2011). Logistics and the competitiveness of canadian supply chains. 01 04, 2015 tarihinde international.gc web sitesi: http://www.international.gc.ca/economisteconmiste/assets/pdfs/research/TPR_2011_GVC/13_Roy_e_FINAL.pdf adresinden alındı

Salahodjaev, R., ve Nazarov, Z. (2013). An econometric approach of computing competitiveness index in human capital. Journal of Applied Economics and Business Research, Cilt(Say1), 51-64.

Sandberg, E., ve Abrahamsson, M. (2011). Logistics Capabilities for Sustainable Competitive Advantage. International Journal of Logistics, 14(1), 61-75.

Sanyal, R. (2005). Determinants of Bribery in International Business: The Cultural and Economic Factors. Journal of Business Ethics, 59(1-2), 139-145.

Schwab, K. (2014). The global competitiveness report . World Economic Forum.

Sofyalığlu, Ç., ve Kartal, B. (2013). Türkiye ve Avrasya ekonomik topluluğu ülkelerinin lojistik performans indekslerinin karşılaştırılması ve bazı çıkarımlar. International Conference on Eurasian Economies, (s. 524- 531).

Şahbaz, A., Koç, A., ve Ata, Y. (2013). Yolsuzluk ve kamu borcu ilişkisi: $\mathrm{AB}$ ülkeleri üzerine ampirik bir inceleme. Akdeniz İ.I.B.F. Dergisi, 13(26), 206-220.

Tanzi, V. (1998). Corruption Around the world; causes, consequences, scope, and cures. IMF Staff Paper, 45(4), 559-594.

Tanzi, V., ve Davoodi, H. (1998). Roads to nowhere: How corruption in public investment hurts growth. International Monetary Fund Economic Issues, 12, 1-12.

TUIKK. (2014). 11 20, 2015 tarihinde TUIK- Türkiye İstatistik Kurumu: http://www.tuik.gov.tr/PreIstatistikMeta.do;jsessionid=np0ZVyJGtTSnGZhQ1QrMvZGnlChLt14L4yBQ7dLfQ0rGlkpMGGLh!1863195282?istab_id=9035 adresinden alınd 1 
Tutar, E., Tutar, F., ve Yetişen, H. (2009). Türkiye'de lojistik sektörünün gelişmişlik düzeyinin seçilmiş AB Ülkeleri (Romanya ve Macaristan) ile karşılaştırmalı analizi. KMU İ̈BF Dergisi, 7(11), 190-216.

Türkay, İ. (2015). Uluslararası şeffaflık örgütü'nün yolsuzluk algılama endeksi ve Türkiye'nin durumu. Vergi Sorunları Dergisi, 317, 129137.

Wang, M. L., Choi, C. H. (2018). How logistics performance promote the international trade volume? A comparative analysis of developing and developed countries. International Journal of Logistics Economics and Globalisation, 7(1), 49-70

Wright, A. S., ve Craigwell, R. (2013). Economic growth and corruption in devolping economies: Evidence from lineer and non-linearpanel causality tests. Journal of Business, Finance ve Economics in Emercing Economies, 7(2), 23-43.

Uca, N., Civelek, M., E., Çemberci, M. (2015). The effects of the components of logistics performance index on gros domestic product: conceptual model proposal. Eurasian Academy of Science Eurasian Business and Economics Journal, 1, 86-93.

Uca, N., İnce, H., Sümen, H. (2016). The mediator effect of logistics performance index on the relation between corruption perception index and foreign trade volume. European Scientific Journal, 12(25), 37-45.

Yakışık, H., ve Çetin, A. (2014). Yolsuzlukların sosyoekonomik belirleyicileri: Yatay kesit veri analizi. Atatürk Üniversitesi İktisadi ve İdari Bilimler Dergisi, 28(3), 205-224.

\section{Kaynakça Bilgisi / Citation Information}

Uca, N., Civelek, M. E. ve Çemberci, M. (2019). Yolsuzluk algısının gayrisafi yurt içi hasıla üzerine etkisinde lojistik performans ile küresel rekabetin ara değişken rolü: Türkiye değerlendirmesi. OPUSUluslararası Toplum Araştırmaları Dergisi , 10(17), 1229-1261. DOI: 10.26466/opus.522497 